\title{
Airway inflammation and structural changes in airway hyper-responsiveness and asthma: An overview
}

\author{
Louis-Philippe Boulet MD FRCPC, Jamila Chakir PhD, Jean Dubé MSc, Catherine Laprise MSc, \\ Michel Boutet MD FRCPC, Michel Laviolette MD FRCPC \\ Unité de Recherche, Centre de Pneumologie de l'Hôpital Laval, Réseau canadien des Centres \\ d'excellence en santé respiratoire, Sainte-Foy, Québec
}

\begin{abstract}
L-P Boulet, J Chakir, J Dubé, C Laprise, M Boutet, M Laviolette. Airway inflammation and structural changes in airway hyper-responsiveness and asthma: An overview. Can Respir J 1998;5(1):16-21.

Asthma treatment has moved from bronchodilator therapy to an emphasis on anti-inflammatory therapy. Airway inflammation is believed to induce airway hyper-responsiveness (AHR) through the release of mediators that increase the airway response to agonists. However, the exact contribution of airway inflammation in the physiology of airway hyper-responsiveness remains undefined. Structural modifications in airways resulting from inflammation may contribute to the development and persistence of AHR and the development of asthma. This paper reviews some of the main components of airway inflammation and structural changes in asthma, and discusses how these processes may interact to modify airway function and induce respiratory symptoms.
\end{abstract}

Key Words: Airway inflammation, Airway remodelling, Asthma, Cytokines, Fibroblast, Subepithelial fibrosis

$\mathrm{B}$ ronchial asthma is characterized by reversible airflow obstruction, airway hyper-responsiveness (AHR) and airway mucosal inflammation (1). The role of inflammation in the development of AHR and symptomatic asthma has been greatly emphasized in the past decade, and asthma treatment has moved from bronchodilator therapy to an emphasis on anti-inflammatory therapy (2). Airway inflammation is believed to induce AHR through the release of mediators
Une vue d'ensemble de l'inflammation des voies aériennes et des changements structuraux dans l'hyperréactivité des voies aériennes et dans l'asthme

RÉSUMÉ : Le traitement de l'asthme, qui auparavant reposait sur l'utilisation de bronchodilatateurs est maintenant axé sur l'utilisation d'anti-inflammatoires. On croit que l'inflammation des voies aériennes induit une hyperréactivité bronchique par le biais de la libération de médiateurs qui augmentent la réponse bronchique aux agonistes. Cependant, la contribution exacte de l'inflammation des voies aériennes dans la physiologie de l'hyperréactivité bronchique reste indéfinie. Les modifications structurales présentes dans les voies aériennes et qui résultent de l'inflammation pourraient contribuer au développement et à la persistance de l'hyperréactivité bronchique et au développement de l'asthme. Le présent article passe en revue certaines des composantes principales de l'inflammation des voies aériennes et des changements structuraux dans l'asthme, et discute de la manière dont ces processus peuvent interagir pour modifier la fonction des voies aériennes et induire des symptômes respiratoires.

that increase the airway response to agonists by their action on smooth muscle contractility, inflammatory cell influx, vascular permeability and mucus secretion $(3,4,5)$.

However, the exact contribution of airway inflammation in the physiopathology of AHR and asthma symptomatology remains undefined (6,7). Recent histopathological data suggest that structural modifications in airways resulting from inflammation may contribute, even more than the inflamma-

Correspondence and reprints: Dr Louis-Philippe Boulet, Hôpital Laval, 2725 Chemin Sainte-Foy, Sainte-Foy, Québec GIV 4 G5. Telephone 418-656-4747, fax 418-656-4762, e-mail lpboulet@med.ulaval.ca 


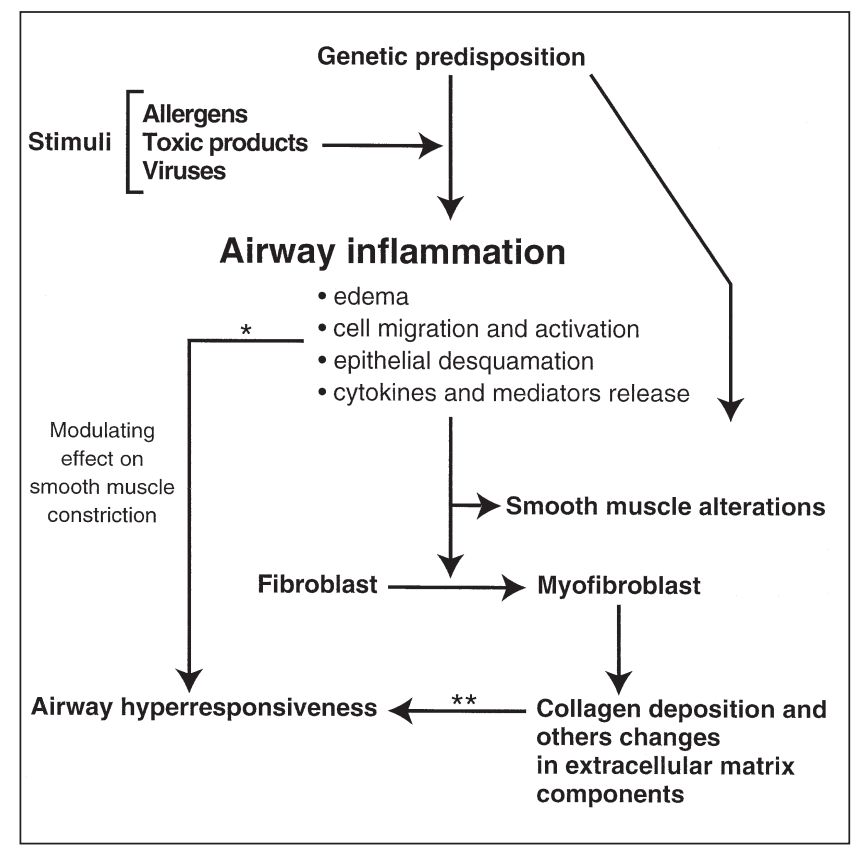

Figure 1) Potential pathways by which inflammation and remodelling can contribute to the development of airway hyperresponsiveness. *Reversible; ** Less reversible

tory insult per se, to the development and the persistence of AHR and influence the development of symptomatic asthma (Figures 1,2) (8-10). The relevance of these various changes and their contribution to the development of abnormal airway function, however, is still obscure. In this report and more extensively in the other papers included in this issue of the Canadian Respiratory Journal, some of the main components of airway inflammation and structural changes in asthma are reviewed, and how these two processes may interact to modify airway function and induce respiratory symptoms are discussed.

\section{AIRWAY INFLAMMATION AND ASTHMA}

Analysis of bronchoalveolar lavage (BAL) cells and bronchial biopsies obtained from asthmatic patients has made it possible to investigate the role of inflammatory and structural changes in the development of AHR and symptomatic asthma (4,5,8,11-12). In sensitized asthmatic subjects, allergen exposure increases both BAL eosinophil and epithelial cell counts $(13,14)$. Microscopy studies of asthmatic airways have shown, even in mild asthma, a cellular infiltrate, mainly of activated lymphocytes and eosinophils, subepithelial collagen deposition, bronchial epithelium disruption, alterations in cilia, subepithelial edema, mucus cell hyperplasia and smooth muscle structural changes $(8,12,15)$. Both natural and laboratory allergen exposures increase the inflammatory features observed in bronchial biopsies $(15,16)$.

These observations support the concept that asthma is an inflammatory disease. However, although a relationship has been found between the airway inflammatory process and AHR, this is not always clinically evident $(4,5-7,17,18)$. Asthma and AHR may persist with only minimal evidence of inflammation (19);

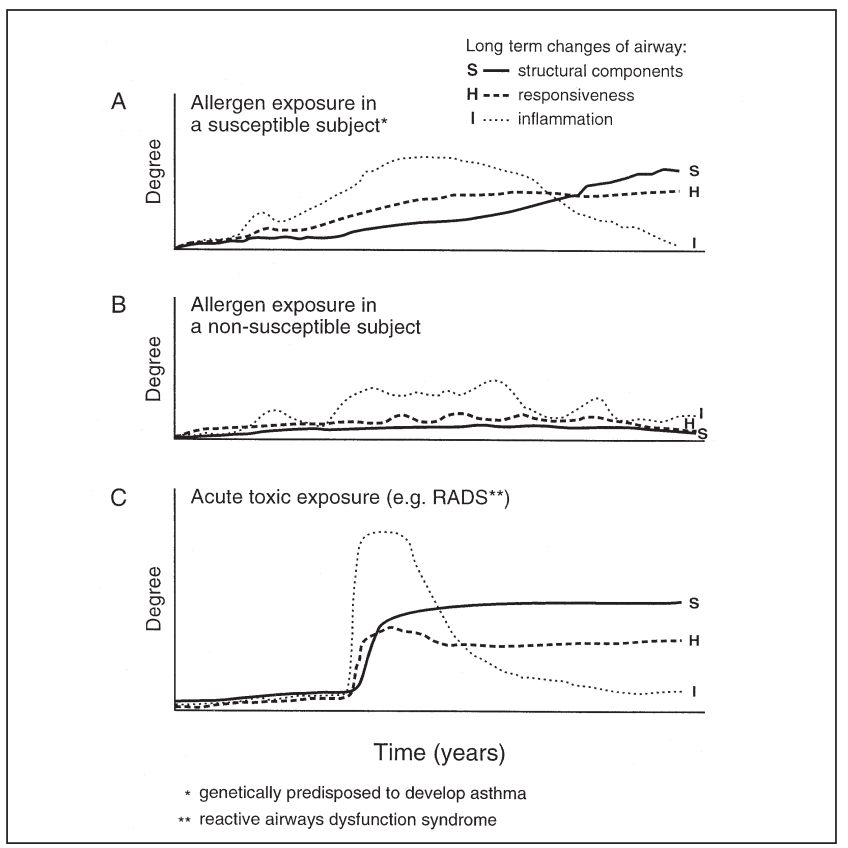

Figure 2) Hypothetical evolution of inflammatory or structural airway changes over time in different types of asthma. RADS Reactive airways dysfunction syndrome

however, persistence of a certain degree of airway inflammation despite the regular use of a clinically adequate dose of inhaled corticosteroids has been reported (20).

\section{CELLS AND CYTOKINES: THE WORLD OF INFLAMMATION}

The acceptance of asthma as an inflammatory disease has not only modified its treatment, but also stimulated research to understand the particular features of asthmatic inflammation. As with other inflammatory responses, many cell types and mediators are involved. The cellular and humoral components of the asthmatic inflammatory response have been previously reviewed $(3,21,22)$ and are discussed in other papers in the symposium; therefore, only a few aspects are discussed.

The cascade of events following allergen exposure, starting with host sensitization (at least in allergic asthma) and airway inflammation, and leading to AHR and asthma symptoms remains to be defined. Although asthma is probably not a 'one cell' or 'one mediator' disease, the associated inflammatory process is characterized by certain predominant features: mast cell activation; lymphocyte and eosinophil activation and recruitment; increased vascular permeability; and epithelial desquamation (4,23-25). Furthermore, a variety of structural alterations have been reported, including goblet cell hypertrophy, smooth muscle hypertrophy or hyperplasia and extracellular matrix modifications, including subepithelial fibrosis $(8,10,12)$. These inflammatory and structural changes probably result from complex positively or negatively orchestrated mechanisms in tissues, including structural cell-immune cell communications via cell-cell contacts, mediator- and cytokine-driven messages and cell-extracellular matrix interactions (26-29). 


\section{PLASMA TRANSUDATION AND AIRWAY WALL THICKNESS}

Plasma transudation may contribute to the increased airway response $(25,30)$. The observation that left ventricular failure and increased pulmonary vascular volume can be associated with an increase in airway responsiveness supports a role for bronchial edema and increased airway fluid content as modulators of airway responsiveness $(31,32)$. An excellent review describes the role of increased airway microvascular permeability in airway inflammation and obstruction (25). The influence of increased airway water content may be only transient, as in heart failure. It is conceivable that airway bloodflow and vascular permeability are increased in asthma as in other inflammatory diseases, and that they can lead to an increased vascular turgidity and plasma transudation in response to chronic and acute inflammation. A model developed by Hogg and coworkers (33) suggests that airway wall thickness can be an important factor in the pathogenesis of AHR and that even a minimal reduction of airway calibre, due to airway submucosal edema, may increase the response to agonists.

\section{AIRWAY STRUCTURE CHANGES IN ASTHMA}

Airways are lined by a pseudostratified, ciliated epithelium with a few goblet cells. In normal subjects there are very few inflammatory cells in the submucosa and the basement membrane is thin (usually 5 to $7 \mu \mathrm{m}$ ), composed of laminin and type IV collagen.

In a comparative analysis of bronchial biopsies obtained from subjects with allergic or occupational asthma, chronic cough or allergic rhinitis, and normal controls, one of the main histological differences found between asthmatic and nonasthmatic subjects was the presence of a linear subepithelial collagen deposition beneath the basement membrane in asthmatic subjects (34). In subjects with rhinitis, a similar collagen deposition was observed, but it was focal and less than that seen in asthmatics. In a global analysis of bronchial biopsy features of the different groups of subjects, the degree of subepithelial fibrosis showed a correlation with AHR to methacholine (34).

The possibility that collagen deposition beneath the layer of smooth muscle may enhance the contractility of the airways is in keeping with the model of Wiggs et al (35). It is possible that the same degree of smooth muscle constriction in an airway wall thickened by collagen deposition beneath the basement membrane or by edema could result in an enhanced airway response to bronchoconstrictor stimuli compared with normal airways, although it is possible that this collagen deposition limits maximal bronchoconstriction. Another mechanism by which airway function may be modified following such changes is the increase in tensile stiffness and resistance to deformation of the airways, explaining the reduction in distensibility described in asthmatic airways (36). This may also prevent full expansion of airways from deep inspiration during bronchial provocation tests, possibly explaining the lack of response to stretch in asthmatic subjects (and reproduced in normal subjects breathing at low lung volumes) noted by Skloot et al (37) and acting to antagonize the bronchodilating effect of a deep inspiration (38). In this regard, the role of changes in surface tension of the airways remains to be studied. Inflammation can alter the integrity of airway epithelium and its surfactant properties, potentially increasing surface tension and making airway opening more difficult compared with the force needed to close them (39).

Increases in airway wall thickness may also be due to hyperplasia and/or hypertrophy of airway smooth muscle (40). Although implicated in the development of AHR, hyperplasia or hypertrophy of smooth muscle is not always present in asthmatics who die of other causes than asthma (41). Furthermore, a recent study published by Thomson et al (42) provided no evidence of increased airway smooth muscle in the large airways of asthmatic subjects, suggesting that differences in the mechanical responses of asthmatic airways could not be solely explained by the amount of smooth muscle. On the other hand, Lambert et al (43) showed that asthmatic airways have fewer intraluminal mucosal folds than constricted normal airways, and that this may lead to greater airway narrowing. Thus, not only may the airway wall thickness influence airway response, but also its responses to contraction, including folding of the submucosa.

Other factors, such as the reduction of lung-airway interdependence because of adventitial edema or increased elastin degradation induced by the inflammatory process, may also increase airway contractility (44). Finally, little is known about the contribution of changes in other airway structures such as cartilage and vessels to changes in airway function.

\section{ORIGIN OF THE AIRWAY SUBEPITHELIAL FIBROSIS}

In asthma, the subepithelial collagen is composed of types III and V collagens and fibronectin $(8,44,45)$. This deposition has been attributed to myofibroblasts (46); the number of myofibroblasts in the subepithelial area of the airways correlates with basement membrane thickness (47). Myofibroblasts are likely to be one of the important cells involved in the changed contractile properties of the airways, following inflammatory insults. Myofibroblasts were initially found on electron micrographs of contracting experimental granulation tissue (48). During normal wound healing, they may temporarily acquire a smooth muscle phenotype in response to an increased contractile functional demand $(49,50)$. When this functional effect is no longer needed, myofibroblasts appear to be replaced by fibroblasts, probably during a dedifferentiation process, with the cell losing its contractile properties.

\section{RELATIONSHIPS BETWEEN INFLAMMATION AND AIRWAY FIBROSIS}

The airway repair process observed in asthma may be initiated or modulated by mediators and cytokines released by lymphocytes, eosinophils, macrophages and mast cells, all of which are increased in asthmatic subjects. Structural cells 
can respond to this chronic inflammatory process by presenting an altered phenotype that may contribute to the chronocity of inflammation (Figure 3). Lymphocytes produce cytokines such as interleukin (IL)-5, IL-3 and granulocyte colony stimulating factor (GM-CSF), which are involved in eosinophil differentiation, maturation and survival $(26,51,52)$. The eosinophil may then accentuate the repair process by continuing damage to the epithelium. Epithelial cells may also be involved in the fibrotic process because they are able to release different mediators and cytokines such as GM-CSF, tumour necrosis factor (TNF) and IL-8 (53). Fibroblasts can be recruited through the influence of monocyte-derived cytokines IL-1 and TNF (54). Activated macrophages and eosinophils also produce tumour growth factor-beta 1 (TGF- $\beta_{1}$ ), which has been shown to allow transformation of fibroblasts into myofibroblasts with actin expression. Desmoulière et al (55) showed that TGF- $\beta_{1}$ plays an important role in myofibroblast differentiation during wound healing and fibrocontractive diseases. After GM-CSF administration, cluster-like accumulations of macrophages play a role in stimulating alpha-smooth muscle actin expression in myofibroblasts (56).

Myofibroblasts are located in the collagen layer $(44,47)$; electron microscopic analysis of these cells showed myofibroblasts with elongated nucleus, peripheral condensation of chromatin and presence of microfilament bundles, indicating a contractile capacity. These fibroblastic cells were isolated from asthmatic and normal bronchial. A portion of these cells express alpha-actin in accord with the in vivo findings. Because these cells express microfilament bundles, the authors tested their capacity to generate contractile forces in comparison with normal bronchial fibroblasts (57). Fibroblasts were mixed with soluble type I collagen. The medium supplemented with serum and contraction was measured by serial area measurements; a higher contractile capacity was found in asthmatic bronchial fibroblasts than in normal cells. This increased contractility was correlated with airway responsiveness to methacholine for day 1 and day 2 .

The importance of these bronchial fibroblasts in the inflammation process remains to be determined. Fibroblasts from different inflammatory sites have a large repertoire of cytokines that mediate immune-mesenchymal interactions. Furthermore, growth factors are probably involved in the fibroblastic proliferation (58). Gauldie et al (27) reported that there may be a persistent phenotypic change of fibroblasts in chronic inflammation and suggested that these altered cells may contribute to the maintenance of the inflammatory process. However, up to now, there is no evidence that such a phenomenon is involved in asthma.

\section{AIRWAY EPITHELIAL ALTERATIONS AND AHR}

Epithelial damage is considered one of the main features of asthma (59). Airway responsiveness correlates with the extent of epithelial desquamation in subjects with AHR, although this correlation is rather weak $(12,34)$. The cause of epithelial shedding is unknown, but it may be related to underlying edema. Beneath the bronchial epithelium, there is a

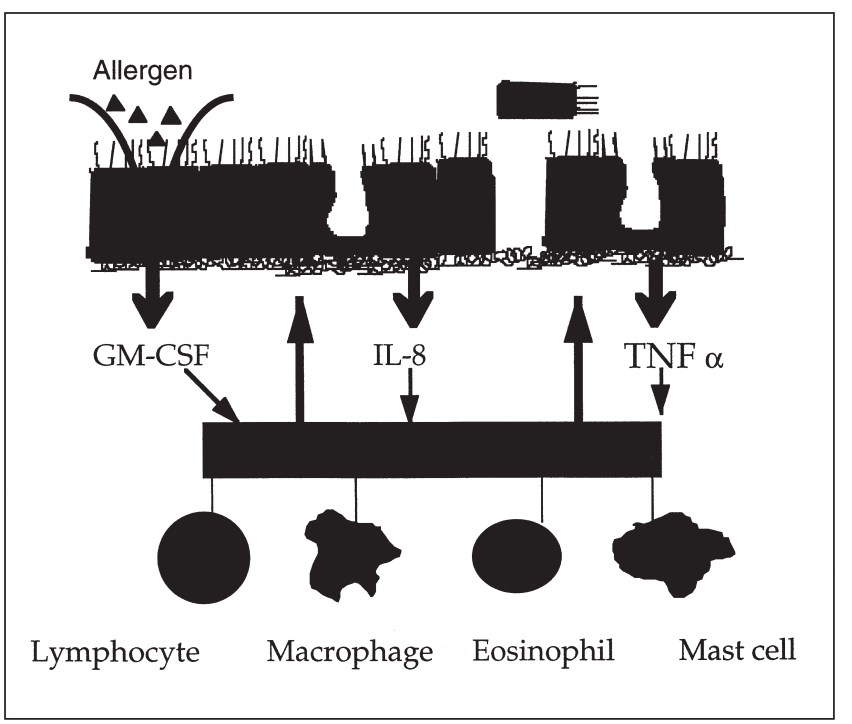

Figure 3) Interactions between airway epithelium and inflammatory cells through the influence of cytokines. GM-CSF Granulocyte colony stimulating factor; IL Interleukin; TNF $\alpha$ Tumour necrosis factor-alpha

rich network of microvessels. Separation of epithelial cells can occur following compression by the increased fluid volume present in the submucosa due to the inflammatoryinduced exudation. In this regard, Montefort et al (60) showed that shedding of epithelial cells occurs along a suprabasal plane of cleavage between suprabasal and basal cell layers, which might be more vulnerable to insults. Underlying airway edema may facilitate this phenomenon due to a physical effect on the attachment of basal and suprabasal cells. Epithelial desquamation is probably enhanced by the effect of toxic substances, such as basic proteins and oxygen radicals, released by eosinophils or other cells (61).

\section{EFFECTS OF THERAPY ON AIRWAY INFLAMMATION AND STRUCTURAL CHANGES}

Anti-inflammatory agents such as corticosteroids reduce airway inflammation, as shown by a decrease in the numbers of airway eosinophils, mast cells and activated lymphocytes and, in most subject, provision of a significant but often partial resolution of airway responsiveness $(7,62,63)$.

Corticosteroids may help to restore epithelial integrity but generally they do not induce asthma remission (64). Furthermore, they are less effective in reducing sub-basement membrane collagen deposition, suggesting that once this process has been underway for months or years, it will not reverse with treatment (65). Improvement in airway responsiveness with corticosteroids may be associated with a reduction of airway wall inflammation, but the persistence of an irreversible AHR may be explained by the fixed structural changes such as airway wall fibrosis. The study by Lundgren (19) is in keeping with this possibility, showing that asthmatic subjects who used inhaled corticosteroids for many years had minimal inflammation but still had AHR and persistent abnormal collagen deposition beneath the basement membrane.

It is possible that airway structural changes can be reversi- 
ble at an early stage of the disease, particularly if treated with potent anti-inflammatory agents such as corticosteroids, but they may become irreversible when the insult persists or is initially severe as seen in the reactive airways dysfunction syndrome (RADS) (66). Irreversible airway structural changes and thickening could lead to persistent airflow obstruction and AHR, as observed in some patients with longstanding asthma without significant smoking history (67).

\section{CONCLUSIONS}

We reviewed some possible mechanisms by which the asthma inflammatory process may lead to persistent AHR and symptomatic asthma, particularly through its influence on airway structure. Asthma is probably due to the effects of environmental stimuli which induce airway inflammation and secondary bronchial structural changes in a genetically predisposed individual. Atopy certainly contributes to such a phenomenon in many individuals, but chemical (industrial) toxic agents or viral infections may also be involved in others. The asthmatic airway inflammatory response can be considered as a defense mechanism, protecting the individual against an exogenous aggression (eg, an allergen), or possibly as an autoimmune response secondary to a latent viral infection or other etiology. If the inflammatory process does not induce any morphological change in the airways, its only manifestation may be a cough via cough receptor stimulation by mediators. If it persists because of repeated or continuous stimulus exposure or persistent alteration of inflammatory cell functions, or if the initial stimulus is severe (as in

\section{REFERENCES}

1. American Thoracic Society Board of Directors. Standards for the diagnosis of patients with COPD and asthma. Am Rev Respir Dis 1987; 136:225-44

2. International consensus report on diagnosis and treatment of asthma. Clin Exp Allergy 1992;22(Suppl 1):1-72.

3. Holgate ST. Mediators and cytokine mechanisms in asthma. Thorax 1993;48:103-9.

4. Azzawi M, Bradley B, Jeffery PK, et al. Eosinophils, T-lymphocytes, mast cells, neutrophils, and macrophages in bronchial biopsy specimens from atopic subjects with asthma: Comparison with biopsy specimens from atopic subjects without asthma and normal control subjects and relationship to bronchial hyperresponsiveness. Am Rev Respir Dis 1992;145:669-74.

5. Kay AB, Wardlaw AJ, Collins JV, Dunnette S, Gleich GJ. Eosinophil and major basic protein in bronchoalveolar lavage in asthma: relationship to non-specific hyperresponsiveness. J Allergy Clin Immunol 1986;77:236-42.

6. McFadden ER Jr, Gilbert IA. Asthma. N Engl J Med 1993;327:1928-37.

7. Power C, Sreenan S, Hurson B, Burke C, Poulter LW. Distribution of immunocompetent cells in the bronchial wall of clinically healthy subjects showing bronchial hyperresponsiveness. Thorax 1993;48:1125-9.

8. Djukanovic R, Roche WR, Wilson JW, et al. Mucosal inflammation in asthma. Am Rev Respir Dis 1990;142:434-57.

9. Stewart AG, Tomlinson PR, Wilson J. Airway wall remodelling in asthma: A novel target for the development of anti-asthma drugs. Trends Pharm Sci 1993;14:275-9.

10. Laitinen LA, Laitinen A. Remodeling of asthmatic airways by glucorticosteroids. J Allergy Clin Immunol 1996;97:153-8.

11. Bousquet J, Chanez P, Lacoste JY, et al. Eosinophilic inflammation in asthma. N Engl J Med 1990;323:1033-9.

12. Jeffery PK, Wardlaw AJ, Nelson FC, Collins JV, Kay AB. Bronchial biopsies in asthma. Am Rev Respir Dis 1989;140:1745-53.
RADS), abnormal repair processes with subepithelial fibrosis will develop, possibly increasing airway contractile properties and leading to the appearance of AHR (Figure 2). Accentuated airway inflammation, particularly airway wall edema, intraluminal secretions and stimulation of neural pathways and changes in airway surface tension, may modulate this increased airway responsiveness. These aspects of inflammation may account for reversible AHR; the addition of structural changes, such as subepithelial airway collagen deposition, may explain an 'irreversible' component. With time, particularly if the remodelling continues, the irreversible component of AHR increases. This hypothesis may explain why individuals can have airway hyper-responsiveness without asthma symptoms (68). It also suggests that early treatment of airway inflammation, perhaps even before asthma symptoms appear, might prevent its symptomatic stage.

Finally, we should not forget that other aspects of airway responses such as the maximal bronchoconstrictor response observed in asthma could also be related to structural or inflammatory airway changes; this topic needs to be explored further. Maximal bronchoconstriction is not always proportional to the degree of AHR, and its mechanisms can be different from those leading to AHR. Of particular interest is the hypothesis of a decreased airway elastance as an explanation for this phenomenon (69).

A significant amount of work remains to be done to determine the contribution of the different inflammatory and structural elements to the physiological and clinical changes in asthma.
13. Aalbers R, Kauffman HF, Vrugt B, et al. Bronchial lavage and broncho-alveolar lavage in allergen-induced single early and dual asthmatic responders. Am Rev Respir Dis 1993;147:76-81.

14. De Monchy JGR, Kauffman HF, Venge P, et al. Bronchoalveolar eosinophilia during allergen-induced late asthmatic reactions. Am Rev Respir Dis 1985;131:373-6.

15. Beasley R, Roche WR, Roberts JA, Holgate ST. Cellular events in the bronchi in mild asthma and after bronchial provocation. Am Rev Respir Dis 1989;139:806-17.

16. Boulet LP, Turcotte H, Boutet M, Laviolette M. Influence of antigenic exposure on expiratory flows, methacholine responsiveness and airway inflammation in mild allergic asthma. J Allergy Clin Immunol 1993;91:883-93.

17. Smith H. Asthma, inflammation, eosinophils and bronchial hyper-responsiveness. Clin Exp Allergy 1992;22:187-97.

18. Rogers DF, O'Connor BJ. AHR: relation to asthma and inflammation? Thorax 1993;48:1095-6.

19. Lundgren R. Scanning electron microscopic studies of bronchial mucosa before and during treatment with beclomethasone diproprionate inhalations. Scand J Respir Dis 1977;101(Suppl):179-87.

20. Sont JK, Han J, van Krieken JM, et al. Relationship between the inflammatory infiltrate in bronchial biopsy specimens and clinical severity of asthma in patients treated with inhaled steroids. Thorax 1996;51:496-502.

21. Cromwell O. Inflammatory cells, mediators and asthma. Eur J Clin Res 1991;2:39-48.

22. Johnston SL, Holgate ST. The inflammatory response in asthma. Br J Hosp Med 1991;46:84-90.

23. Gleich GJ. The eosinophil and bronchial asthma: current understanding. J Allergy Clin Immunol 1990;85:422-36.

24. Synek M, Beasley R, Frew AJ, et al. Cellular infiltration of the airways in asthma of varying severity. Am J Respir Crit Care Med 1996;154:224-30. 
25. Coldie RG, Pedersen KE. Mechanisms of increased airway microvascular permeability: role in airway inflammation and obstruction. Clin Exp Pharmacol Physiol 1995;22:387-96.

26. Holgate ST, Djukanovic R, Howarth PH, Montefort S, Roche W. The $\mathrm{T}$ cell and the airway's fibrotic response in asthma. Chest 1993; 103:125S-8S

27. Gauldie J, Jordana M, Cox G, Ohtoshi T, Dolovich J, Denburg J. Fibroblasts and other structural cells in airway inflammation. Am Rev Respir Dis 1992;145:S14-7.

28. Litchfield TM, Lee TH. Asthma: Cells and cytokines. J Asthma 1992;29:181-91.

29. Birkedal-Hansen H. Role of cytokines and inflammatory mediators in tissue destruction. J Periodont Res 1993;28:500-10.

30. Persson CGA, Erjefält I, Alkner U, et al. Plasma exsudation as a first line respiratory mucosal defence. Clin Exp Allergy 1991;21:17-24.

31. Cabanes LR, Weber SN, Matran R, et al. Bronchial hyperresponsiveness to methacholine in patients with impaired left ventricular function. N Engl J Med 1989;320:1317-22.

32. Regnard J, Baudrillard P, Salah B, Xuan ATD, Cabanes L, Lockhart A. Inflation of antishock trousers increases bronchial response to methacholine in healthy subjects. J Appl Physiol 1990;68:1528-33.

33. Hogg JC, Paré PD, Moreno R. The effect of submucosal edema on airways resistance. Am Rev Respir Dis 1987;135(Suppl):S56-8.

34. Boulet LP, Laviolette M, Turcotte H, et al. Bronchial subepithelial fibrosis correlates with airway responsiveness to methacoline. Chest 1997; 112:45-52.

35. Wiggs BR, Bosken C, Paré PD, James A, Hogg JC. A model of airway narrowing in asthma and in chronic obstructive pulmonary disease. Am Rev Respir Dis 1992;145:1251-8.

36. Wilson JW, Li X, Pain MC. The lack of distensibility of asthmatic airways. Am Rev Respir Dis 1993;148:806-9.

37. Skloot C, Permutt S, Togias A. Airway hyperresponsiveness in asthma: a problem of limited smooth muscle relaxation with inspiration. J Clin Invest 1995:2393-403.

38. Wheatley JR, Paré P, Engel LA. Reversibility of induced bronchoconstriction by deep inspiration in asthmatic and normal subjects. Eur Respir J 1989;2:331-9.

39. Yap DY, Liebkemann WD, Solway J, Gaver DP. Influences of parenchymal tethering on the reopening of closed pulmonary airways. J Appl Physiol 1994;76:2095-105.

40. Sobonya RE. Quantitative structural alterations in long-standing allergic asthma. Am Rev Respir Dis 1984;130:289-92.

41. Ebina Yaegashi H, Chiba R, Takahasmi T, Motomiya M, Tanemura M. Hyperreactive site in the airway tree of asthmatic patients revealed by thickening of bronchial muscles. A morphometric study. Am Rev Respir Dis 1990;141:1327-32.

42. Thomson RJ, Bramley AM, Schellenberg RR. Airway smooth muscle stereology: implications for increased shortening in asthma. Am J Respir Crit Care Med 1996;154:749-57.

43. Lambert RK, Wiggs BR, Kuwano K, Hogg JC, Paré PD. Functional significance of increased airway smooth muscle in asthma and COPD. J Appl Physiol 1993;74:2771-81.

44. Roberts C. Asthma as a fibrotic disease. Chest 1995;107:111S-8S.

45. Chakir J, Laviolette M, Boutet M, Laliberté R, Dubé J, Boulet LP. Lower airways remodelling in nonasthma subjects with allergic rhinitis. Lab Invest 1996;75:735-44

46. Roche WR. Fibroblasts and asthma. Clin Exp Allergy 1991;21:545-8

47. Brewster CE, Howarth P, Djukanovic R, Wilson J, Holgate ST. Myofibroblasts and subepithelial fibrosis in bronchial asthma. Am J Respir Cell Mol Biol 1990;3:507-11.

48. Schürch W, Seemayer TA, Gabbiani G. Myofibroblast. In: Sternberg S. Histology for Pathologists. New York: Raven Press Ltd, 1992:109-44.

49. Darby I, Skalli O, Seemayer TA, et al. Myofibroblasts from diverse pathologic settings are heterogeneous in their content of actin isoforms and intermediate filaments proteins. Lab Invest 1989;60:275-85.
50. Darby I, Skalli O, Gabbiani G. Smooth muscle actin is temporarily expressed by myofibroblasts during experimental wound healing. Lab Invest 1990;63:19-21.

51. Wilson JW, Djukanovic R, Howarth P, Holgate ST. Lymphocyte activation in bronchoalveolar lavage and peripheral blood of atopic asthma. Am Rev Respir Dis 1992;145:958-60.

52. Moqbel R. Eosinophils, cytokines, and allergic inflammation. Ann NY Acad Sci 1994;725:223-33.

53. Marim M, Saloporte M, Mezzetti M, Fasoli A, Mattoli S. Interleukin-1 binds to specific receptor on human epithelial cells and upregulates granulocyte macrophage colony-stimulating factor synthesis and release. Am J Respir Cell Mol Biol 1991;4:519-24.

54. Sappino AP, Schürch W, Gabbiani G. Differentiation repertoire of fibroblastic cells: expression of cytoskeletal proteins as marker of phenotypic modulations. Lab Invest 1990;63:144-61.

55. Desmoulière A, Geinoz A, Gabbiani F, Gabbiani G. Transforming growth factor-1 induces alpha-smooth muscle actin expression in granulation tissue myofibroblasts and in quiescent and growing cultured fibroblasts. J Cell Biol 1993;122:103-11.

56. Vyalov S, Desmoulière A, Gabbiani G. GM-CSF induced granulation tissue formation: relationship between macrophage and myofibroblast accumulation. Vichows Arch B Cell Pathol 1993;63:231-9.

57. Goulet F, Boulet LP, Chakir J, et al. Morphologic and functional properties of broncial cells isolated form normal and asthmatic subjects. Am J Respir Cell Mol Biol 1996;15:312-8.

58. Rifkin DB, Moscatelli D. Recent developments in the cell biology of basic fibroblast growth factor. J Cell Biol 1989;109:1-6.

59. Laitinen LA, Heino M, Laitinen A, Kava T, Haahtela T. Damage of the airway epithelium and bronchial responsiveness in patients with asthma. Am Rev Respir Dis 1985;131:599-606.

60. Montefort S, Roberts JA, Beasley R, Holgate ST, Roche WR. The site of disruption of the bronchial epithelium in asthmatic and non-asthmatic subjects. Thorax 1992;47:499-503.

61. Montefort S, Herbert CA, Robinson C, Holgate ST. The bronchial epithelium as a target for inflammatory attack in asthma. Clin Exp Allergy 1992;22:511-20.

62. Djukanovic R, Walls A, Wilson JW, et al. The effect of inhaled beclomethasone dipropionate (BDP) on airway mast cells, histamine and tryptase. Am Rev Respir Dis 1991;143:A627.

63. Juniper EF, Kline PA, Vanzieleghem MA, Ramsdale EH, O'Byrne P, Hargreave FE. Effect of long-term treatment with inhaled corticosteroids on airway hyperresponsiveness and clinical asthma in non steroid-dependent asthmatics. Am Rev Respir Dis 1990;142:832-6

64. Laitinen LA, Laitinen A, Haahtela T. A comparative study of the effects of an inhaled corticosteroid, budesonide, and a beta 2-agonist, terbutaline, on airway inflammation in newly diagnosed asthma: a randomized, double-blind, parallel-group controlled trial. J Allergy Clin Immunol 1992;90:32-42.

65. Jeffery PK, Godfrey RW, Ädelroth E, Nelson F, Rogers A, Johansson SA. Effects of treatment on airway inflammation and thickening of basement membrane reticular collagen in asthma. Am Rev Respir Dis 1992;145:890-9

66. Gautrin D, Boulet LP, Dugas M, et al. Is reactive airway dysfunction syndrome (RADS) a variant of occupational asthma? J Allergy Clin Immunol 1994;93:12-22.

67. Hudon C, Turcotte H, Boutet M, Laviolette M, Carrier G, Boulet LP. Characteristics and determinants of bronchial asthma with incomplete reversibility of airflow obstruction: a fibrotic disease. Ann Allergy Asthma Immunol 1997;78:195-202.

68. Boulet LP, Turcotte H, Brochu A, Characteristics of asthma in remission: Persistence of airway hyperresponsiveness. Chest 1994;105:1024-31.

69. Bramley AM, Thomson RJ, Roberts CR, Schellenberg RR. Hypothesis: excessive bronchoconstriction in asthma is due to decreased airway elastance. Eur Respir J 1994;7:337-41. 


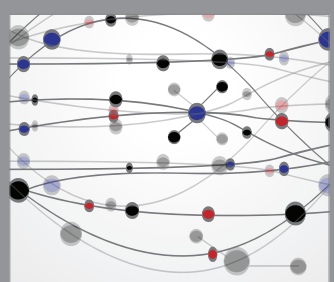

The Scientific World Journal
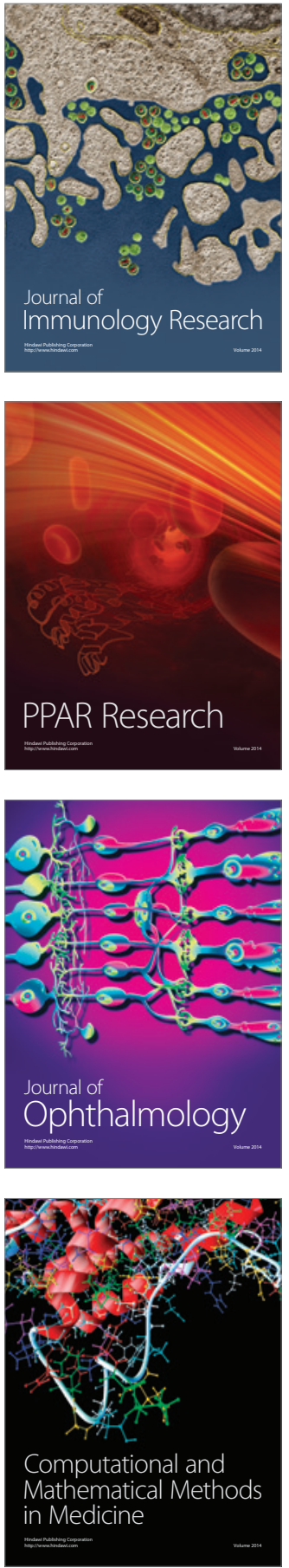

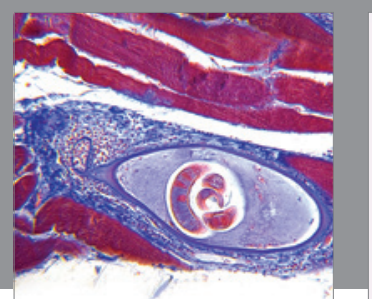

Gastroenterology Research and Practice

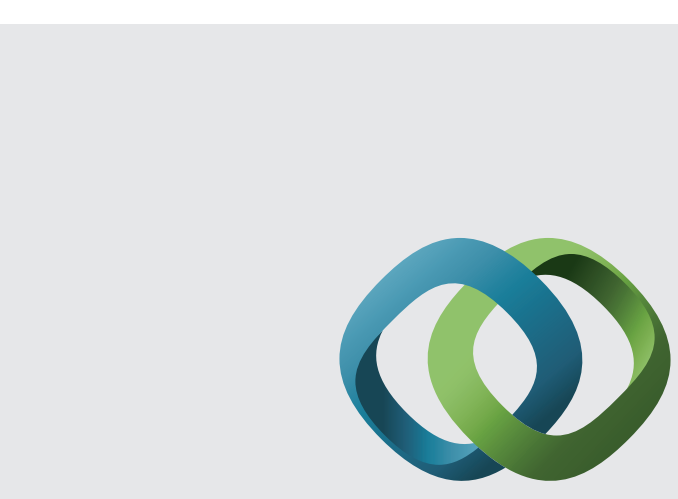

\section{Hindawi}

Submit your manuscripts at

http://www.hindawi.com
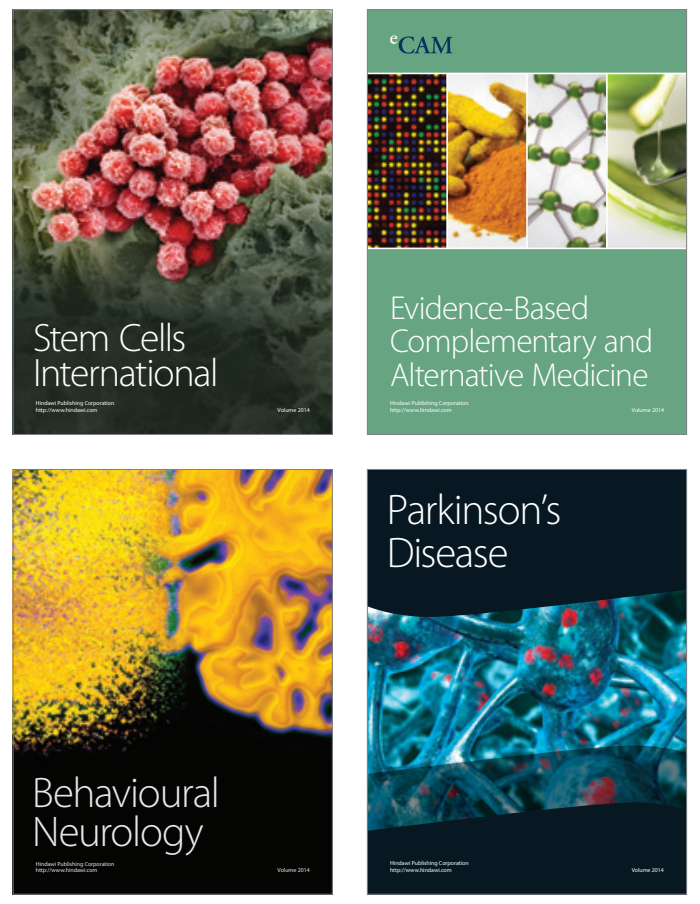
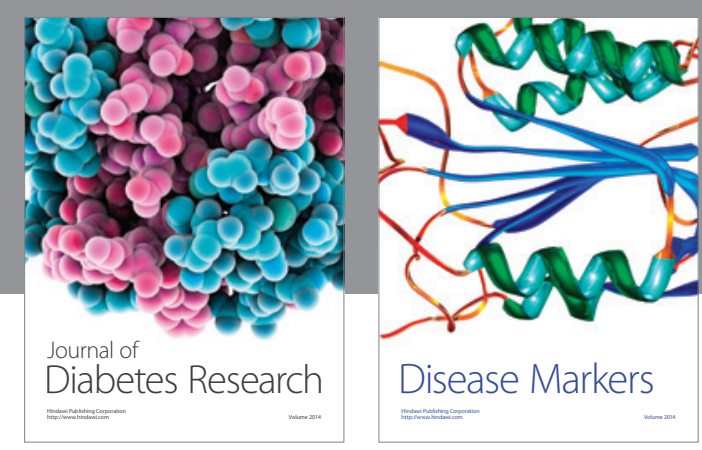

Disease Markers
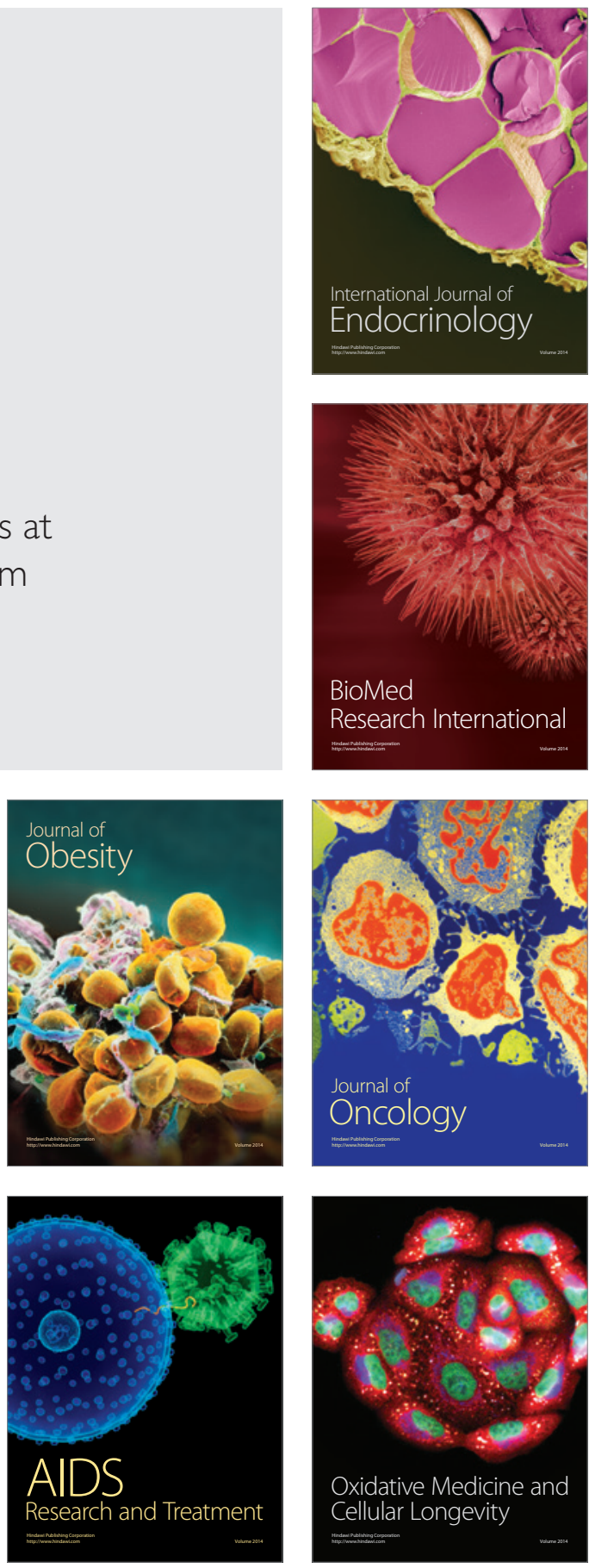